\title{
UTILIZATION OF REAPER AS AN ALTERNATIVE SYSTEM FOR LITTER REMOVAL INSIDE BROILER HOUSES \\ Basiouny, M. A. ${ }^{1}$ and S. E. Abdallah ${ }^{2}$ \\ 1- Agric. Eng. Res. Inst. (AEnRI), Giza, Egypt. \\ 2- Agric. Eng. Dept., Fac. of Agric., Kafrelsheikh Univ., Egypt.
}

\begin{abstract}
A new test to identify the modified reaper has been developed for broiler litter removal. The present study describes in detail the efficacy of this new method on broiler litter removal efficiency. Tests were carried out to select the appropriate operating parameters for this purpose. The results of these experiments were graphed to show and examine the differences associated with the choice of the independent variable. It appears that the highest values of $1018.89 \mathrm{~m}^{2} / \mathrm{h}$ effective field capacity and of $84.89 \%$ field efficiency were achieved at the operating conditions of $45.4 \%$ w.b. litter moisture content, $1.2 \mathrm{~km} / \mathrm{h}$ reaper travel speed and $2^{\circ}$ shovel blade tilt angle. In contrast, the lowest values of $330.96 \mathrm{~m}^{2} / \mathrm{h}$ effective field capacity and of $55.16 \%$ field efficiency were achieved at the operating conditions of $35.7 \% \mathrm{w} . \mathrm{b} ., 0.6 \mathrm{~km} / \mathrm{h}$ and $8^{\circ}$. It could be demonstrated that the differences between the highest and lowest values were of 207.8 and $\mathbf{5 3 . 9 \%}$ increment for the effective field capacity and field efficiency respectively. Similar results were obtained for the remaining parameters. However, in this case, the differences between the highest and lowest values were of 19.30, $210.94,124.21$ and $210.64 \%$ increment for the litter removal efficiency, reaper output, unit energy and unit operating cost respectively. It was quite evident that, from cost estimates, the labor participation revealed the highest cost parameter percentage of 44.09. Contrariwise, the lowest cost parameter percentage of 10.23 was attributed to fuel and lubrication. In all circumstances, the equipment has proved efficient and cost effective during extensive use.
\end{abstract}

\section{INTRODUCTION}

Broiler litter is a waste material which can be recognized as a combination of accumulated droppings (manure) and bedding material from poultry production. The common bedding materials are wheat hay, rice straw, rice and peanut hulls, shredded sugar cane, wood shavings, sawdust and other dry, absorbent, low-cost organic materials. Sand is also occasionally used as bedding. The Broiler litter is removed from poultry houses after the birds have been raised. It is a valuable source of minerals $(4 \%$ nitrogen, $1.56 \%$ phosphorus and $2.3 \%$ potassium) for soil fertilization and a biomass resource for bioenergy applications (Allam, in Arabic, 1994; McMullen et al., 2004; Fasina et al., 2006 and Bernhart et al., 2007). Most expansions of broiler houses, in Egypt, are only vertical expansions because of the decrease of agrarian plot. This has led to many obstacles in removing the litter, using the mechanized methods, from the ground of the multi-floor broiler houses after each production (rearing) cycle. Introduction of appropriate machinery is one of the major factors for reducing labor requirements and production costs (Alizadeh et al., 2007). This requires a suitable machine in qualities such as size, mass and performance to remove 
the litter. Therefore, it was an urgent question to make full use of the reaper in removing litter from the floor of these broiler houses. This can be easier when those broiler houses are provided with elevators to serve the higher floors in lifting fodders and rations. This system in its turn makes lifting the studied machine to the higher floors an easy task. Reaper (harvester) is a machine to cut (reap) grain crops such as rice, wheat and barley, etc. It has the peculiarity of the simple configuration and reasonable structure, which is convenient for maintenance, with the advantages of small volume, lightweight, low energy consumption, stable performance, good reliability and strong applicability. Therefore, it is very suitable to small fields, mountainous areas and hill (Sahay, 2004 and FMMCR, 2008). So, the main goal of this paper is to maximize the reaper utilization in litter removal from the ground floor of broiler houses.

\section{MATERIALS AND METHODS}

To meet with the objectives of the current investigation, some parts of the reaper are replaced and modified to serve as an alternative system to remove the broiler litter and to maximize the utilization of reaper in another purpose except harvesting.

\section{Reaper (Harvester):}

The original function of the reaper is to reap or harvest rice, wheat and barely etc. Crop is guided and conveyed to the right side by the conveyer belt. Reaper is powered by an engine attached with it. One person is required to orientate the machine. It consists of a metal frame, a pair of rubber wheels, an engine, power transmission system and harvesting unit. The reaper is coupled with a number of hitch points on the orientation handle grip for adjusting its inclination with the ground level. This machine is discriminated, during its repair and maintenance, with the simplicity of untying and construction. For instance, the harvesting unit can be taken to pieces out of the reaper keeping all the remaining components constant. The whole specifications of reaper are listed in Table 1.

\section{Suggested Modifications:}

In this paper, the harvesting unit was taken to pieces and replaced by a shovel with the purpose of removing litter from the ground floor of broiler houses. The local raw materials such as iron sheets were employed to fabricate the shovel with $2 \mathrm{~mm}$ thick for its bottom and $1 \mathrm{~mm}$ thick for the rest. The shovel bottom was covered with a rubber lining to reduce friction with the concrete floors of the farm, especially in the higher floors. The operating width, side width and height of the shovel were of $1.0,0.56$ and $0.40 \mathrm{~m}$ respectively. Its heaped capacity was about of $0.15 \mathrm{~m}^{3}$, estimated on the basis of shovel geometrical shape. The shovel was coupled with an unmoved knife along with its operating width. The side width of knife was of $6 \mathrm{~cm}$. Shovel was fixed at the reaper chassis by means of two steel arms. In addition, there are a number of hitch points along the sides of shovel and chassis for controlling and changing the shovel blade tilt angle with the ground level. The complete fixation of shovel with the reaper chassis was 
done using a proper wick, which tied between the point above the middle of shovel and chassis. Emptying the shovel load was accomplished by reaper inclination to the forwards. Detailed specifications of the modified reaper are indicated in Table 1. Moreover, a diagram of the experimental shovel and a geometrical drawing of the modified reaper are illustrated in Figs 1 and 2 respectively. The suggested modification in this study was fulfilled in one of the workshops at the Industrial City, Kafr Elsheikh Governorate.

Table 1: Specifications of the original and modified reaper.

\begin{tabular}{|c|c|c|}
\hline Item & Reaper (harvester) & Reaper after modification \\
\hline Function & $\begin{array}{l}\text { Reap (harvest) rice, whea } \\
\text { and barley, etc. }\end{array}$ & $\begin{array}{l}\text { Litter removal from the ground } \\
\text { floor of broiler houses. }\end{array}$ \\
\hline Manufacturer & Japan & Japan (except the shovel) \\
\hline Dimensions: & & \\
\hline Overall length, m & 2.39 & 2.40 \\
\hline Overall width, m & 1.47 & 1.20 \\
\hline Overall height, $\mathrm{m}$ & 0.90 & 0.90 \\
\hline Mass, kg & 116 & 117.5 (full empty shovel) \\
\hline Engine: & & \\
\hline Type & 4 - Cycle, air-cooled & 4 - Cycle, air-cooled \\
\hline Model & GS 130-2CN & GS $130-2 \mathrm{CN}$ \\
\hline Displacement & $130 \mathrm{cc}$ & 130cc \\
\hline $\begin{array}{l}\text { Fuel } \\
\text { Fuel tank volume }\end{array}$ & $\begin{array}{l}\text { gasoline } \\
\text { 3liters }\end{array}$ & gasoline \\
\hline The modified part & Harvesting unit & Shovel \\
\hline Ground contact & A pair of rubber wheels & A pair of rubber wheels \\
\hline device & & \\
\hline Steering & Manual & Manual \\
\hline
\end{tabular}

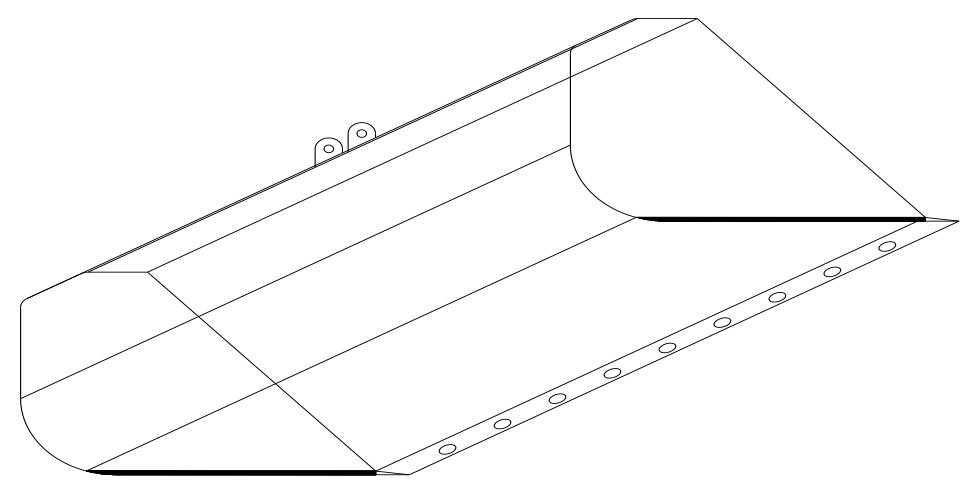

Fig. 1: Diagram of the experimental shovel.

\section{Broiler Litter:}

The investigated litter is a mixture of broiler droppings and chopped rice straw. The mean length of chopped rice straw in litter ranged between 5 to $8 \mathrm{~cm}$. Using a metal ruler, twenty five readings were taken at different and randomized positions of the farm ground to calculate the litter depth. The 
averaged litter depth was estimated by about of $3.78 \mathrm{~cm}$. The modified reaper was tested in removing litter after rearing cycle of broilers. The broiler farm consists of three floors and its ground was concrete. The farm was equipped with a lever to elevate and lower the machine. Alongside, the removed litter was brought down by the lever. Broiler farm is located at Misseer Village, Kafr Elsheikh Governorate.

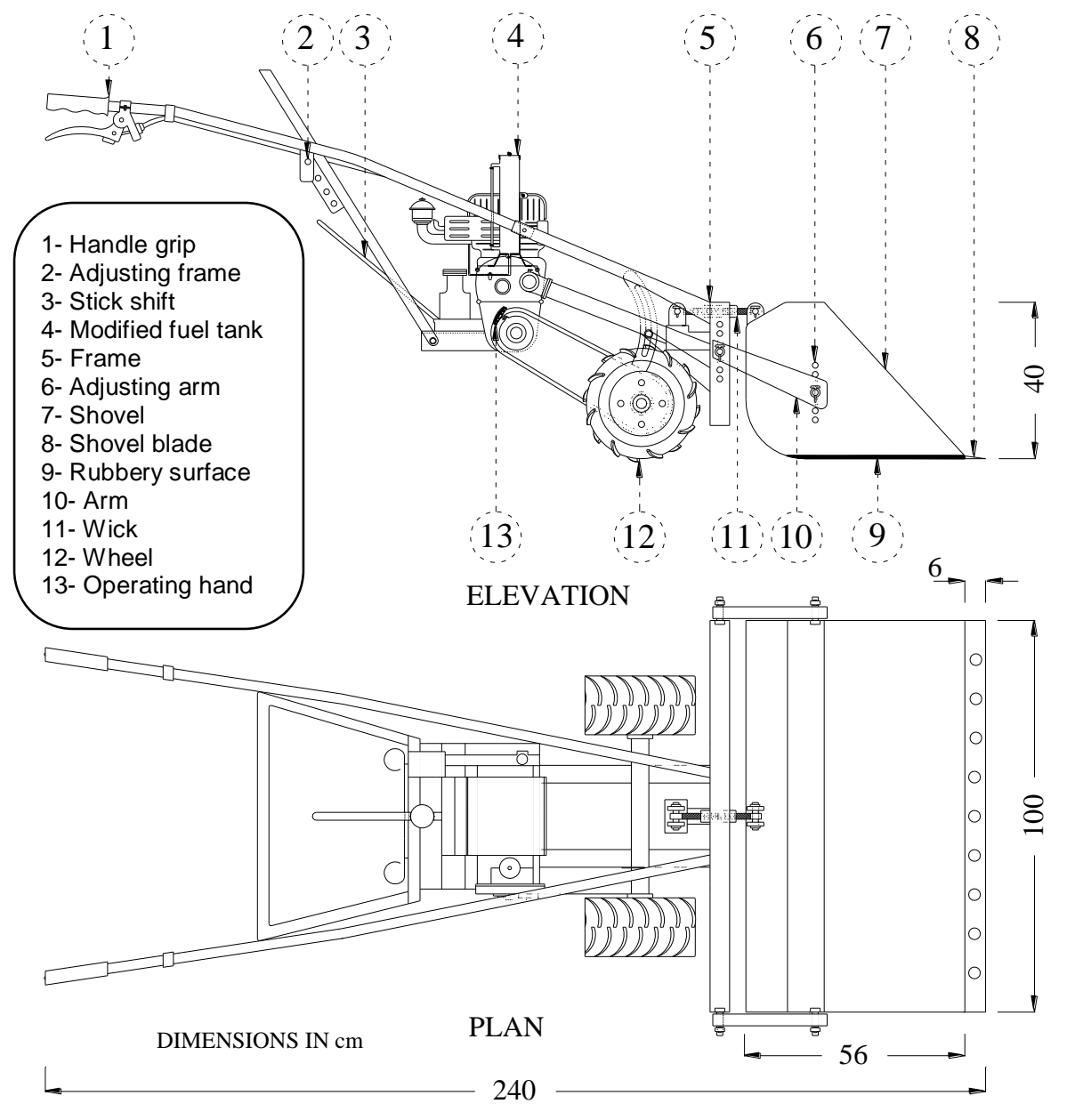

Fig. 2: A perspective of the alternative broiler litter removal system (the modified reaper).

\section{Studied Factors:}

Performance characteristics of the modified reaper were demonstrated as affected by three operating factors as follows:

- Litter moisture content of 35.7, 40.6 and $45.4 \%$ w.b.; 
- Reaper travel speed of $0.6,0.9$ and $1.2 \mathrm{~km} / \mathrm{h}$ and

- Shovel blade tilt angle of 2,5 and $8^{\circ}(0.0349,0.0873$ and $0.1396 \mathrm{rad})$ respectively (Fig. 3).

The optimum operating conditions of the modified reaper were evaluated and determined for all the levels of studied factors. Multiple regression analyses were done to represent the experimental data in linear forms.
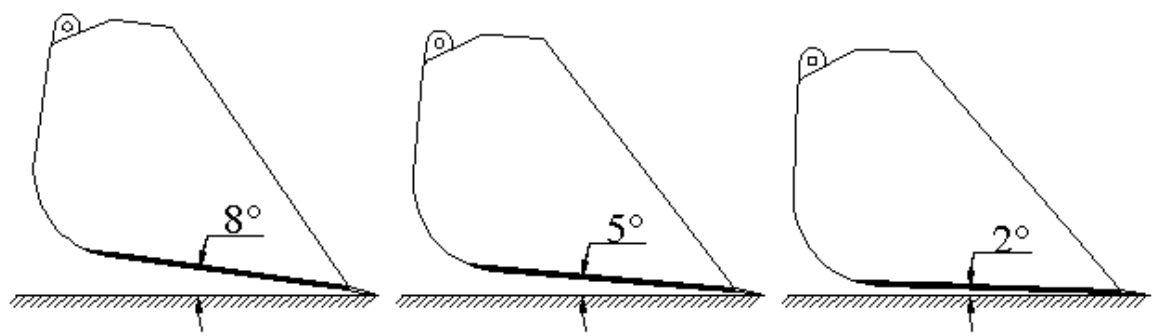

Fig. 3: Schematic drawing of the shovel blade tilt angles.

\section{Measuring Instruments:}

Moisture content of broiler litter was determined using the oven method according to AOAC, 1985. Reaper travel speed was measured by a digital tachometer and expressed in rpm. After that it was converted to a linear speed in terms of $\mathrm{km} / \mathrm{h}$. Inclination of shovel blade with the ground surface level was measured by a wooden protractor. A fuel tank with the capacity of about 0.5 liter was fabricated and connected with the reaper engine. This fuel tank consists of tank, hand valve and graduated scale for monitoring the fuel consumption in terms of milliliters (Fig. 4). Consequently, the energy consumption could be easily calculated. A stopwatch was used for accounting loading and whole lost time, in which the effective field capacity can be estimated.

\section{Procedures:}

Effective Field Capacity $\left(F C_{E}\right), \mathbf{m}^{2} / \mathrm{h}$ :

$$
F C_{E}=\frac{60}{T_{l}+T_{i}}
$$

Where;

$T_{l} \quad$ is the loading time, $\mathrm{min} / \mathrm{m}^{2}$ and

$T_{i} \quad$ is the summation of the lost time (adjusting, turning, discharging and repairing time, etc.), $\mathrm{min} / \mathrm{m}^{2}$.

Field Efficiency $(F E)$, \%:

$F E=\frac{F C_{E}}{F C_{T}} \times 100$ 


\section{Basiouny, M. A. and S. E. Abdallah}

Where;

$F C_{T}$ is the theoretical field capacity, $\mathrm{m}^{2} / \mathrm{h}$.

$F C_{T}=W \times S \times 10^{3}$

Where;

$W \quad$ is the shovel operating width, $\mathrm{m}$ and

$S \quad$ is the reaper travel speed, $\mathrm{km} / \mathrm{h}$.

Litter Removal Efficiency (LRE), \%:

$L R E=\frac{M_{s}}{M_{s}+M_{r}} x 100$

Where;

$M_{s} \quad$ is the litter mass loaded into the shovel, $\mathrm{kg}$ and

$M_{r} \quad$ is the remaining litter mass on the ground floor after loading shovel, $\mathrm{kg}$.

Reaper Output $(R O), \mathbf{m}^{3} / \mathbf{h}$ :

$R O=F C_{E} x D \times L R E$

Where;

$L R E$ is the litter removal efficiency, decimal and

$D \quad$ is the mean depth of litter layer, $\mathrm{m}$

Unit Energy, kW.h/m $\mathbf{m}^{3}$ :

The power consumption requirements were calculated according to the formula of Hunt (1984) as follows:

Powerconsumption, $k W=\frac{F C x \rho_{f} x L C V \times 427 \times \eta_{m} \times \eta_{t h}}{3600 \times 75 \times 1.36}$

Where;

$F C \quad$ is the fuel consumption, $\ell / \mathrm{h}$;

$\rho_{f} \quad$ is the fuel density, $\mathrm{kg} / \ell$ (for gasoline $=0.72$ );

$L C V$ is the lower calorific value of fuel $(11000 \mathrm{kcal} / \mathrm{kg})$;

427 is the thermo-mechanical equivalent, $\mathrm{kg} . \mathrm{m} / \mathrm{kcal}$;

$\eta_{m} \quad$ is the engine mechanical efficiency, (for Otto engine $=85 \%$ ) and

$\eta_{t h} \quad$ is the engine thermal efficiency, (for Otto engine $=25 \%$ ).

Then, the unit energy requirements can be calculated as follows:

Unitenergy, $k W . h / m^{3}=\frac{\text { Powerconsumption }(k W)}{\text { Reaperoutput }\left(m^{3} / h\right)}$

Total Cost, LE/h:

Total cost requirements of the modified reaper include fixed and operating costs. Declining balance method was used to determine the 
depreciation (Hunt, 1983). The unit operating cost could be estimated from the following formula:

Unitoperatingcost, $L E / \mathrm{m}^{3}=\frac{\text { Reapercost }, L E / h}{\text { Reaperoutput } \mathrm{m}^{3} / \mathrm{h}}$

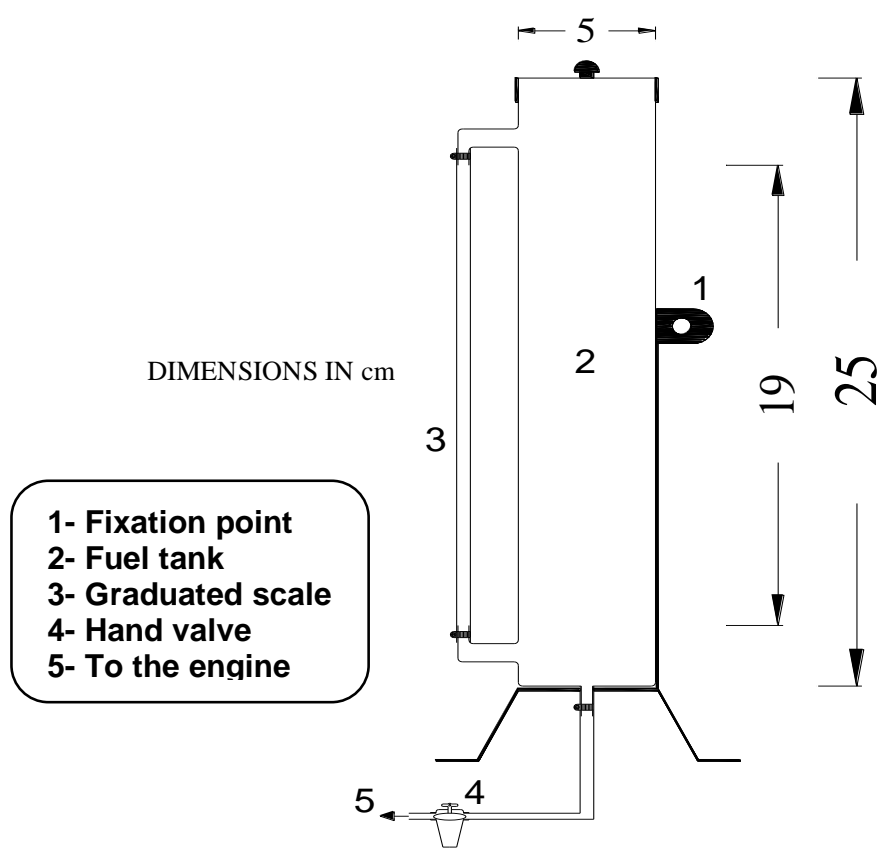

Fig. 4: The fuel consumption device.

\section{RESULTS AND DISCUSSION}

The idea of employing a simple reaper to serve as an alternative system for removing the broiler litter was introduced. The reaper performance parameters as affected by litter moisture content, reaper travel speed and shovel blade tilt angle were also investigated.

\section{Effective Field Capacity:}

Variation of the effective field capacity as affected by reaper travel speed at different levels of litter moisture content and shovel blade tilt angle is illustrated in Fig. 5. From the histograms of Fig. 5, it is obvious that effective field capacity increased with the increase in litter moisture content and reaper travel speed and the decrease in shovel blade tilt angle. At 35.7\%w.b. and $0.6 \mathrm{~km} / \mathrm{h}$, effective field capacity decreased from 356.10 to $330.96 \mathrm{~m}^{2} / \mathrm{h}(-$ $7.06 \%)$ by increasing shovel blade tilt angle from 2 to $8^{\circ}(+300 \%)$. At $0.9 \mathrm{~km} / \mathrm{h}$ and $5^{\circ}$, effective field capacity increased from 550.26 to $709.92 \mathrm{~m}^{2} / \mathrm{h}$ $(+29.02 \%)$ by increasing litter moisture content from 35.7 to $45.4 \%$ w.b. $(+27.17 \%)$. At $40.6 \%$ w.b. and $8^{\circ}$, effective field capacity increased from 
383.64 to $840.24 \mathrm{~m}^{2} / \mathrm{h}(+119.02 \%)$ by increasing reaper travel speed from 0.6 to $1.2 \mathrm{~km} / \mathrm{h}(+100 \%)$. The highest value of $1018.68 \mathrm{~m}^{2} / \mathrm{h}$ effective field capacity was obtained at the conditions of $45.4 \%$ w.b. litter moisture content, $1.2 \mathrm{~km} / \mathrm{h}$ reaper travel speed and $2^{\circ}$ shovel blade tilt angle. Whilst, the lowest value of $330.96 \mathrm{~m}^{2} / \mathrm{h}$ was obtained at $35.7 \%$ w.b., $0.6 \mathrm{~km} / \mathrm{h}$ and $8^{\circ}$. The difference between the highest and lowest values of effective field capacity could be estimated by $207.8 \%$ increment.

\section{Field Efficiency:}

Variation of the field efficiency as affected by reaper travel speed at different levels of litter moisture content and shovel blade tilt angle is shown in Fig. 5. The general trend from Fig. 5 is that field efficiency increased with the increase in litter moisture content and reaper travel speed and the decrease in shovel blade tilt angle. At $1.2 \mathrm{~km} / \mathrm{h}$ and $8^{\circ}$, field efficiency increased from 62.51 to $81.86 \%(+30.96 \%)$ by increasing litter moisture content from 35.7 to $45.4 \%$ w.b. At $45.4 \%$ w.b. and $0.9 \mathrm{~km} / \mathrm{h}$, field efficiency decreased from 81.64 to $78.11 \%(-4.32 \%)$ by increasing shovel blade tilt angle from 2 to $8^{\circ}$. At $35.7 \%$ w.b. and $5^{\circ}$, field efficiency increased from 58.14 to $63.11 \%(+8.55 \%)$ by increasing reaper travel speed from 0.6 to $1.2 \mathrm{~km} / \mathrm{h}$. The highest value of $84.89 \%$ field efficiency was obtained at $45.4 \%$ w.b., $1.2 \mathrm{~km} / \mathrm{h}$ and $2^{\circ}$. Whilst, the lowest value of $55.16 \%$ was obtained at $35.7 \%$ w.b., $0.6 \mathrm{~km} / \mathrm{h}$ and $8^{\circ}$. The difference between the highest and lowest values of field efficiency could be estimated by $53.9 \%$ increment.

\section{Litter Removal Efficiency:}

The variation of litter removal efficiency with the reaper travel speed at different levels of litter moisture content and shovel blade tilt angle is depicted in Fig. 6. From the curves of Fig. 6, it can be generalized that there was an increase in litter removal efficiency as the reaper travel speed decreased and both of litter moisture content and shovel blade tilt angle increased. At $35.7 \%$ w.b. and $1.2 \mathrm{~km} / \mathrm{h}$, litter removal efficiency increased from 82.35 to $85.43 \%(+3.74 \%)$ as shovel blade tilt angle increased from 2 to $8^{\circ}$. At $0.6 \mathrm{~km} / \mathrm{h}$ and $8^{\circ}$, the litter removal efficiency increased from 90.57 to $98.24 \%(+8.47 \%)$ by increasing litter moisture content from 35.7 to $45.4 \%$ w.b. At $40.6 \%$ w.b. and $2^{\circ}$, litter removal efficiency decreased from 92.34 to $89.43 \%(-3.15 \%)$ as reaper travel speed increased from 0.6 to $1.2 \mathrm{~km} / \mathrm{h}$. The highest value of $98.24 \%$ litter removal efficiency was obtained at $45.4 \%$ w.b., $0.6 \mathrm{~km} / \mathrm{h}$ and $8^{\circ}$. Whilst, the lowest value of $82.35 \%$ (the highest litter losses or the remaining of $17.65 \%$ ) was obtained at $35.7 \%$ w.b., $1.2 \mathrm{~km} / \mathrm{h}$ and $2^{\circ}$. The difference between the highest and lowest values of litter removal efficiency could be estimated by $19.30 \%$ increment.

\section{Reaper Output:}

Effect of reaper travel speed on its output at different levels of litter moisture content and shovel blade tilt angle is demonstrated in Fig. 7. From the histograms of Fig. 7, it is revealed that reaper output increased with the increase in litter moisture content and its travel speed and the decrease in shovel blade tilt angle. At $35.7 \%$ w.b. and $0.6 \mathrm{~km} / \mathrm{h}$, reaper output decreased from 12.04 to $11.33 \mathrm{~m} 3 / \mathrm{h}(-5.90 \%)$ as shovel blade tilt angle increased from 2 to $8^{\circ}$. At $40.6 \%$ w.b. and $2^{\circ}$, reaper output increased from 14.13 to $29.68 \mathrm{~m}^{3} / \mathrm{h}$ $(+110.05 \%)$ by increasing its travel speed from 0.6 to $1.2 \mathrm{~km} / \mathrm{h}$. 
J. Agric. Sci. Mansoura Univ., 34 (5), May, 2009

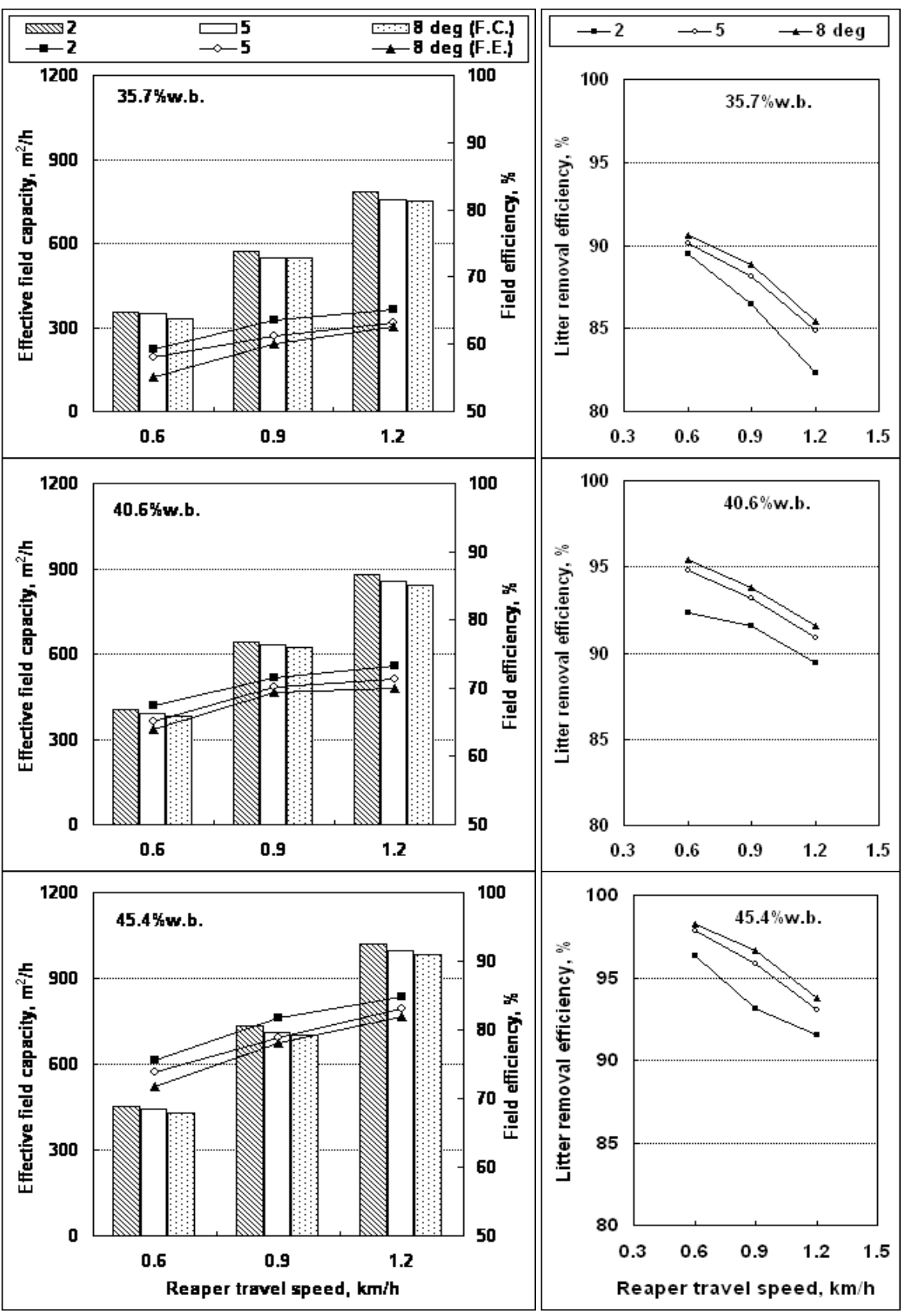

Fig. 5: Variation of effective field capacity and field efficiency as affected by reaper travel speed at different levels of litter moisture content and shovel blade tilt angle.

Fig. 6: The variation of litter removal efficiency as affected by reaper travel speed at different levels of litter moisture content and shovel blade tilt angle. 


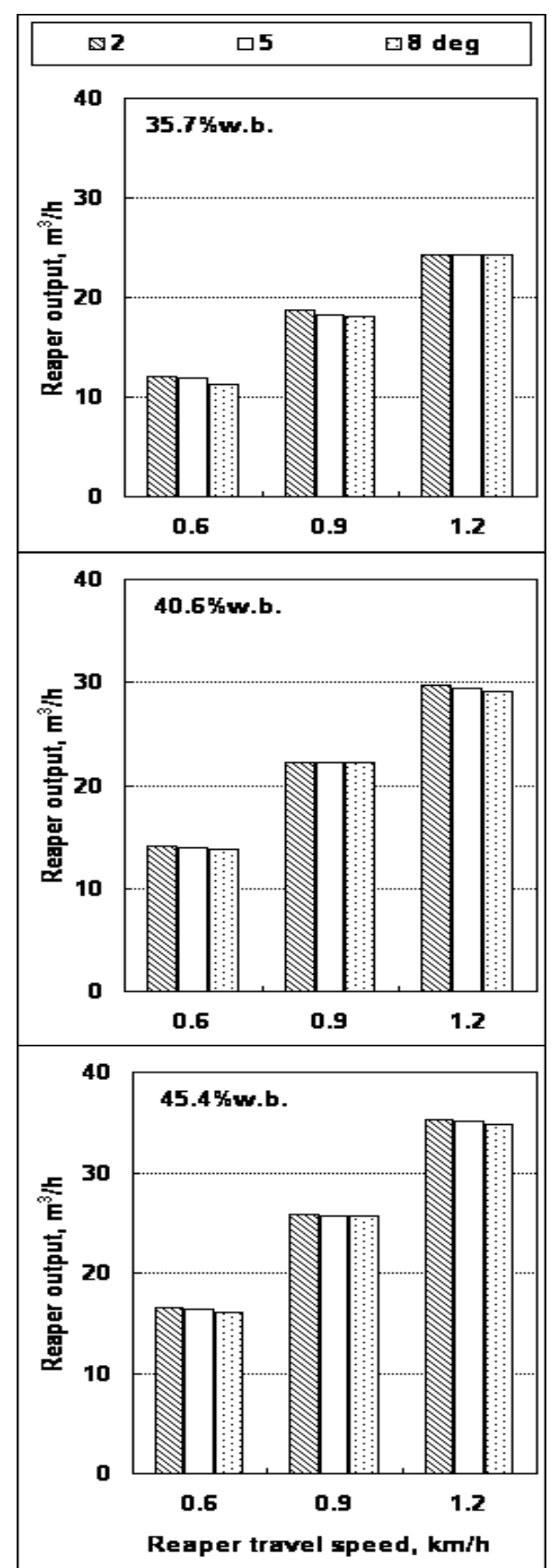

Fig. 7: Effect of reaper travel speed on its output at different levels of litter moisture content and shovel blade tilt angle.

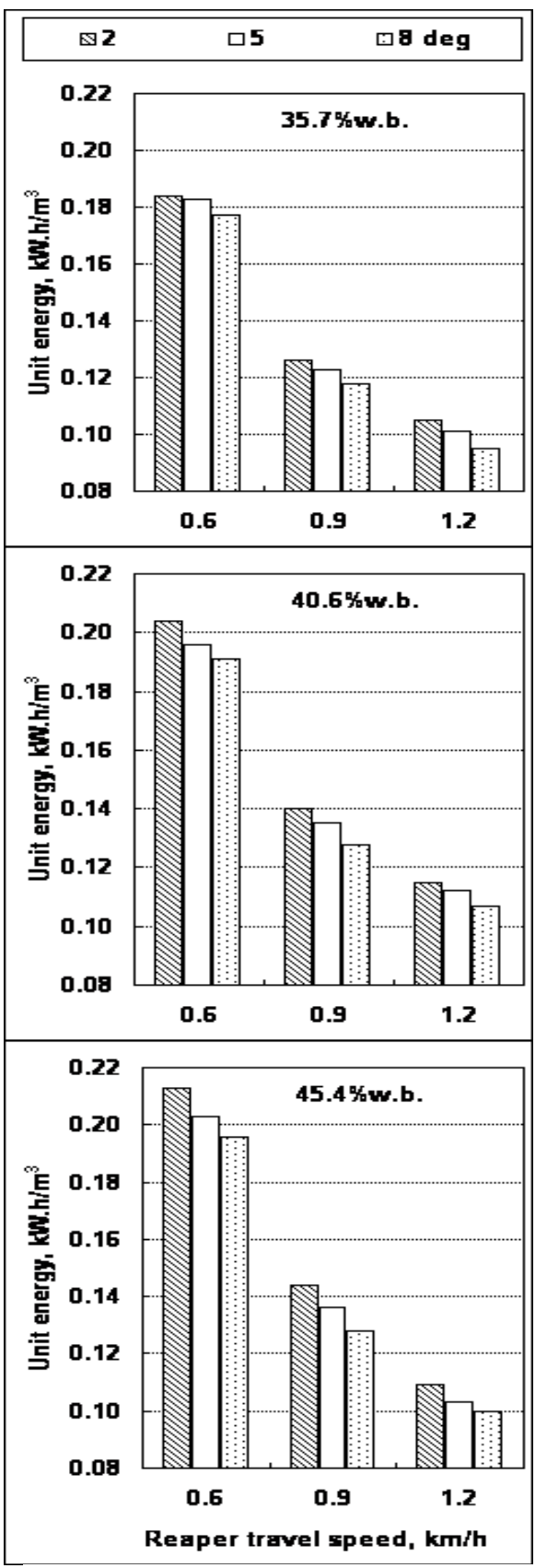

Fig. 8: Unit energy against reaper travel speed for different levels of litter moisture content and shovel blade tilt angle. 
At $0.9 \mathrm{~km} / \mathrm{h}$ and $5^{\circ}$, reaper output increased from 18.33 to $25.73 \mathrm{~m}^{3} / \mathrm{h}$ (+40.37\%) as litter moisture content increased from 35.7 to $45.4 \%$ w.b. The highest value of $35.23 \mathrm{~m}^{3} / \mathrm{h}$ reaper output was obtained at the conditions of $45.4 \%$ w.b., $1.2 \mathrm{~km} / \mathrm{h}$ and $2^{\circ}$. Whilst, the lowest value of $11.33 \mathrm{~m}^{3} / \mathrm{h}$ was obtained at $35.7 \%$ w.b., $0.6 \mathrm{~km} / \mathrm{h}$ and $8^{\circ}$. The difference between the highest and lowest values of reaper output could be estimated by $210.94 \%$ increment.

Unit Energy:

Unit energy against reaper travel speed for different levels of litter moisture content and shovel blade tilt angle is illustrated in Fig. 8. From the histograms of Fig. 8, it can be generalized that unit energy decreased with the increase in reaper travel speed and shovel blade tilt angle and the decrease in litter moisture content. At $35.7 \%$ w.b. and $1.2 \mathrm{~km} / \mathrm{h}$, unit energy decreased from 0.105 to $0.095 \mathrm{~kW} . \mathrm{h} / \mathrm{m}^{3}(-9.52 \%)$ as shovel blade tilt angle increased from 2 to $8^{\circ}$. At $40.6 \%$ w.b. and $5^{\circ}$, unit energy decreased from 0.196 to $0.112 \mathrm{~kW} \cdot \mathrm{h} / \mathrm{m}^{3}(-42.86 \%)$ as the reaper travel speed increased from 0.6 to $1.2 \mathrm{~km} / \mathrm{h}$. At $0.9 \mathrm{~km} / \mathrm{h}$ and $2^{\circ}$, unit energy increased from 0.126 to 0.144 $\mathrm{kW} . \mathrm{h} / \mathrm{m}^{3}(+14.29 \%)$ as litter moisture content increased from 35.7 to $45.4 \%$ w.b. The highest value of $0.213 \mathrm{~kW} . \mathrm{h} / \mathrm{m}^{3}$ unit energy was obtained at the conditions of $45.4 \%$ w.b., $0.6 \mathrm{~km} / \mathrm{h}$ and $2^{\circ}$. Whilst, the lowest value of $0.095 \mathrm{~kW} . \mathrm{h} / \mathrm{m}^{3}$ was obtained at $35.7 \%$ w.b., $1.2 \mathrm{~km} / \mathrm{h}$ and $8^{\circ}$. The difference between the highest and lowest values of unit energy could be estimated by $124.21 \%$ increment.

Unit Operating Cost:

Values of the unit operating cost at different levels of litter moisture content, reaper travel speed and shovel blade tilt angle are listed in Table 2. From the data of Table 2, it is indicated that unit operating cost increased by increasing shovel blade tilt angle and by decreasing both of litter moisture content and reaper travel speed. At $35.7 \%$ w.b. and $0.9 \mathrm{~km} / \mathrm{h}$, unit operating cost increased from 0.849 to $0.874 \mathrm{LE} / \mathrm{m}^{3}(+2.94 \%)$ as shovel blade tilt angle increased from 2 to $8^{\circ}$. At $40.6 \%$ w.b. and $8^{\circ}$, unit operating cost decreased from 1.147 to $0.546 \mathrm{LE} / \mathrm{m} 3(-52.40 \%)$ as reaper travel speed increased from 0.6 to $1.2 \mathrm{~km} / \mathrm{h}$. At $1.2 \mathrm{~km} / \mathrm{h}$ and $8^{\circ}$, unit operating cost decreased from 0.655 to $0.456 \mathrm{LE} / \mathrm{m}^{3}(-30.38 \%)$ as litter moisture content increased from 35.7 to $45.4 \%$ w.b. The highest value of $1.401 \mathrm{LE} / \mathrm{m}^{3}$ unit operating cost was obtained at the conditions of $35.7 \%$ w.b., $0.6 \mathrm{~km} / \mathrm{h}$ and $8^{\circ}$. Whilst the lowest value of $0.451 \mathrm{LE} / \mathrm{m}^{3}$ was obtained at $45.4 \%$ w.b., $1.2 \mathrm{~km} / \mathrm{h}$ and $2^{\circ}$. The difference between the highest and lowest values of unit operating cost could be estimated by $210.64 \%$ increment. Estimates of annual global cost for the modified reaper during litter removal operation are listed in Table 3 and percentages of those cost parameters are depicted in Fig. 9. From Fig. 9, it can be demonstrated that the highest percentage of 44.09 cost parameter was belonging to labor. In contrast, the lowest one of $10.23 \%$ cost parameter was belonging to fuel and lubrication. From Table 3 , it can be noticed that the estimated operating cost of reaper was of 4450LE/year. The annual global cost was of $6350.83 \mathrm{LE} / \mathrm{year}$. Whilst, the hourly reaper cost was estimated as 15.877LE. 
Table 2: Values of the unit operating cost at different levels of litter moisture content, reaper travel speed and shovel blade tilt angle.

\begin{tabular}{|c|c|c|c|c|}
\hline \multirow{2}{*}{$\begin{array}{l}\text { Litter moisture } \\
\text { content, \%w.b. }\end{array}$} & \multirow{2}{*}{$\begin{array}{l}\text { Reaper travel } \\
\text { speed, } \mathrm{km} / \mathrm{h}\end{array}$} & \multicolumn{3}{|c|}{ Unit operating cost, LE/m ${ }^{3}$} \\
\hline & & $2^{\mathrm{O}}$ & $5^{\mathrm{O}}$ & $8^{\mathrm{O}}$ \\
\hline \multirow{3}{*}{35.7} & 0.6 & 1.318 & 1.337 & 1.401 \\
\hline & 0.9 & 0.849 & 0.866 & 0.874 \\
\hline & 1.2 & 0.652 & 0.653 & 0.655 \\
\hline \multirow{3}{*}{40.6} & 0.6 & 1.123 & 1.133 & 1.147 \\
\hline & 0.9 & 0.713 & 0.714 & 0.717 \\
\hline & 1.2 & 0.535 & 0.540 & 0.546 \\
\hline \multirow{3}{*}{45.4} & 0.6 & 0.962 & 0.968 & 0.993 \\
\hline & 0.9 & 0.614 & 0.617 & 0.618 \\
\hline & 1.2 & 0.451 & 0.452 & 0.456 \\
\hline
\end{tabular}

Table 3: Estimation of annual global cost for the modified reaper during litter removal operation.

\begin{tabular}{|l|c|}
\hline No. of years (used before) & 6 \\
\hline Remaining value, LE & 6411.54 \\
\hline Fixed cost, LE/year: & - \\
a) Depreciation & $\mathbf{1 1 3 1 . 4 5}$ \\
b) Interest on investment, taxes, insurance and shelter & 769.38 \\
\hline The fixed cost, LE/year & 1900.83 \\
\hline Operating hours/year & 400 \\
\hline Operating cost, LE/year: & 1000 \\
a) Repairs and maintenance & 650 \\
b) Fuel + lubrication & 2800 \\
\hline c) Labor & 4450 \\
\hline The operating cost, LE/year & 6350.83 \\
\hline Reaper cost, LE/year & 15.877 \\
\hline Reaper cost, LE/h & \\
\hline
\end{tabular}

Six multiple linear regression equations were developed to describe the relationship between the reaper performance parameter as a dependent variable and litter moisture content, reaper travel speed and shovel blade tilt angle as independent variables. The following equation was presented:

$I P=a_{o}+b_{1} M+b_{2} S+b_{3} \theta$

Where;

$I P \quad$ is the investigated reaper performance parameter;

$M \quad$ is the litter moisture content, \%w.b.;

$S \quad$ is the reaper travel speed, $\mathrm{km} / \mathrm{h}$;

$\theta \quad$ is the tilt angle of the shovel blade, deg;

$a_{o} \quad$ is the $y$-intercept and

$b_{1}, b_{2} a n d b_{3}$ are the regression coefficients.

As indicated in Table 4, accuracy of the six relationships was measured by determination coefficient $\left(R^{2}\right)$. 


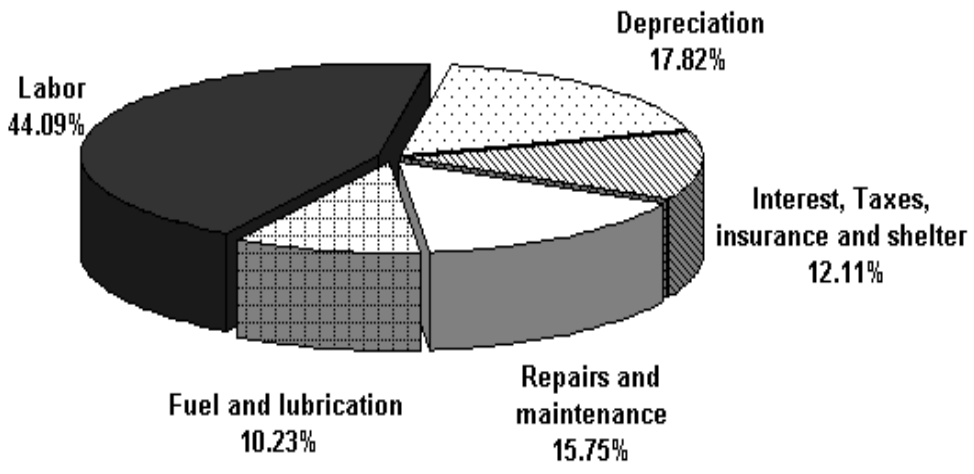

Fig. 9: Percentage of cost parameters for the modified reaper in litter removal inside broiler houses.

Table 4: Multiple linear regression equations, describing the broiler litter removal operation using the modified reaper.

\begin{tabular}{|l|c|c|c|c|c|}
\hline \multicolumn{1}{|c|}{$\begin{array}{c}\text { Performance } \\
\text { Parameter }\end{array}$} & $\begin{array}{c}\text { Y- } \\
\text { Intercept } \\
\left(\boldsymbol{a}_{\mathbf{o}}\right)\end{array}$ & \multicolumn{2}{|c|}{ Regression Coefficients } & $\begin{array}{c}\text { Determination } \\
\text { Coefficient } \\
\left(\boldsymbol{B}^{2}\right)\end{array}$ \\
\hline Effective field capacity, $\mathrm{m}^{2} / \mathrm{h}$ & -751.99 & +17.00 & +800.02 & -4.76 & 0.986 \\
\hline Field efficiency, \% & -13.45 & +1.85 & +11.99 & -0.55 & 0.982 \\
\hline Litter removal efficiency, \% & +64.09 & +0.80 & -7.82 & +0.40 & 0.954 \\
\hline Reaper output, $\mathrm{m}^{3} / \mathrm{h}$ & -32.70 & +0.78 & +25.94 & -0.07 & 0.978 \\
\hline Unit energy, $\mathrm{kW} . \mathrm{h} / \mathrm{m}^{3}$ & +0.23 & +0.01 & -0.15 & -0.01 & 0.932 \\
\hline Unit operating cost, $\mathrm{LE} / \mathrm{m}^{3}$ & +2.85 & -0.03 & -1.01 & +0.01 & 0.944 \\
\hline
\end{tabular}

\section{CONCLUSION}

This paper summarizes the evaluation of modified reaper and outlines compromises between cost, performance and its ease of operation. In conclusion, this work provides the following highlights:

- The effective field capacity and field efficiency of the modified reaper were directly proportional to the reaper travel speed and litter moisture content. Whilst, they were inversely proportional to the shovel blade tilt angle.

- The highest percentage of 98.24 litter removal efficiency was achieved at $8^{\circ}$ shovel blade tilt angle, $0.6 \mathrm{~km} / \mathrm{h}$ reaper travel speed and $45.4 \% \mathrm{w} . \mathrm{b}$. litter moisture content. Furthermore, the highest value of $35.23 \mathrm{~m}^{3} / \mathrm{h}$ reaper output was obtained at $2^{\circ}, 1.2 \mathrm{~km} / \mathrm{h}$ and $45.4 \% \mathrm{w} . \mathrm{b}$. operating conditions.

- The lowest consumed energy for the unit was of $0.095 \mathrm{~kW} . \mathrm{h} / \mathrm{m}^{3}$ at the operating conditions of $8^{\circ}, 1.2 \mathrm{~km} / \mathrm{h}$ and $35.7 \%$ w.b. In addition, the lowest cost for removing one cubic metre of litter was of $0.451 \mathrm{LE}$ at $2^{\circ}, 1.2 \mathrm{~km} / \mathrm{h}$ and $45.4 \%$ w.b. operating conditions. 


\section{REFERENCES}

Alizadeh, M. R.; I. Bagheri and H. Payman (2007). Evaluation of a rice reaper used for rapeseed harvesting. American-Eurasian J. Ag. and Environ. Sci., 2(4): 388-394.

AOAC (1985). Official methods of analysis, association of official analytical chemists. Washington, D. C. USA.

Bernhart, M.; O. Fasina and J. Fulton (2007). Characterization of Poultry Litter for Storage and Process Design. ASAE Paper No. 076050, Am. Soc. Ag. Eng. and Biological Eng., St. Joseph, Michigan. www. asabe. org. Access on November 16, 2008.

FMMCR (2008). Farm Machinery Manufacturing Company Report. Yancheng City, Jiangsu Province, China. www.made-in-china.com. Access on December 14, 2008.

Fasina, O.; J. Fulton; P. Srivastava; W. Wood and F. Owsley (2006). Volume Reduction Technologies for Transporting Poultry Litter. ASAE Paper No. 066173, Am. Soc. Ag. Eng. and Biological Eng., St. Joseph, Michigan. www. asabe. org. Access on November 16, 2008.

Hunt, D. (1983). Farm power and machinery management. $8^{\text {th }}$ Ed. lowa State Univ. Press, Ames., U.S.A., 59-71.

Hunt, D. (1984) Farm power and machinery management. $8^{\text {th }}$ Ed. lowa state Univ., Press Ames, U.S.A., 364-368.

McMullen, J.; O. Fasina; W. Wood; Y. Feng and G. Mills (2004). Physical Characteristics of Pellets from Poultry Litter. ASAE Paper No. 046005, Am. Soc. Ag.. Eng. and Biological Eng., St. Joseph, Michigan. www. asabe. org. Access on November 16, 2008.

Sahay, J. (2004). Elements of agricultural engineering (farm power, farm machinery, farm processing, farm electricity). Nai Sarak, Delhi-110 006, India.

$$
\text { علام ، س. ( §9 } 9 \text { ()). تربية الدو اجن ور عايتها، الطبعة الثامنة ـ دار الطباعة الحديثة. }
$$

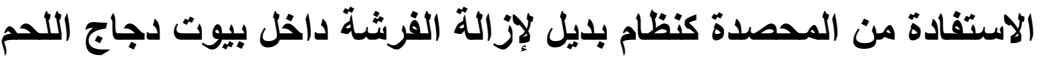

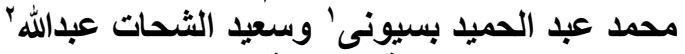

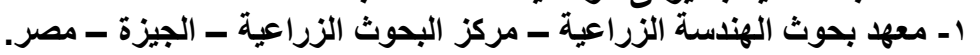

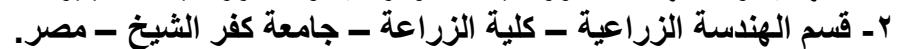

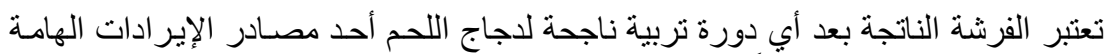

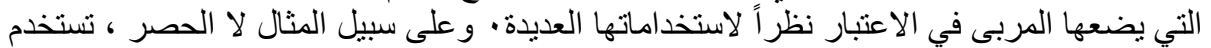

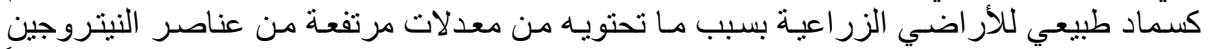

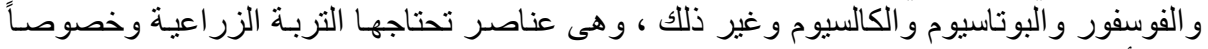

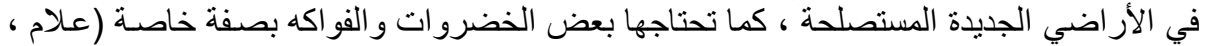

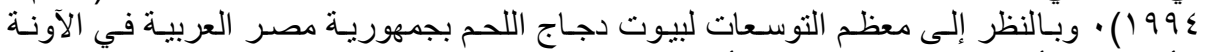

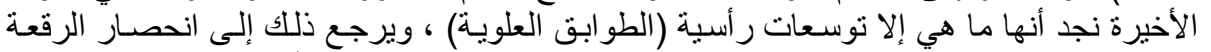

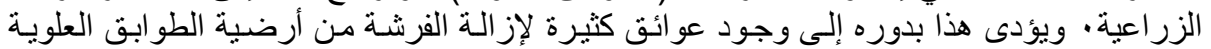

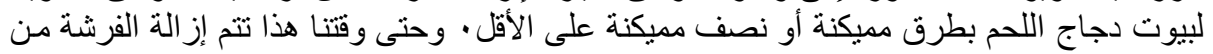


الأرضية بدوياً ، مما يؤدى ذلك إلى ارتفاع تكاليف الإنتاج للمربى، بجانب خطر تعرض نسبة كبيرة

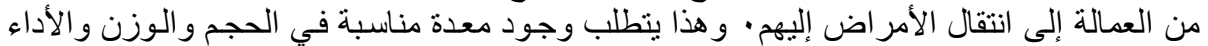

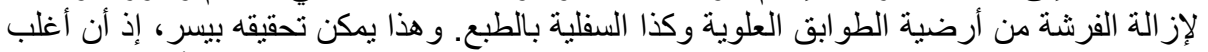

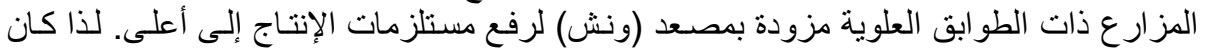

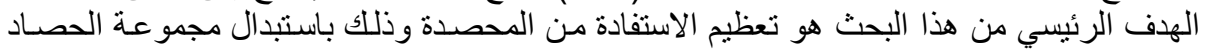

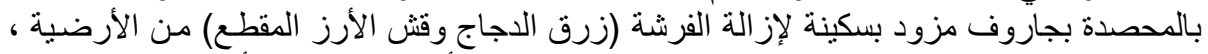

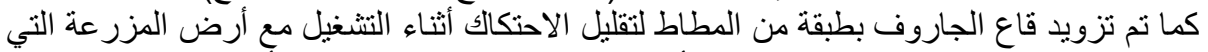

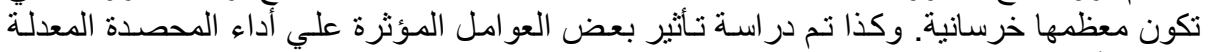
لاختيار أنسب ظروف تشغيل لها بعد التعديل و هـى كالآتي:

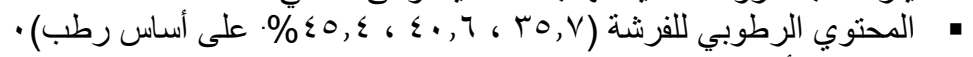

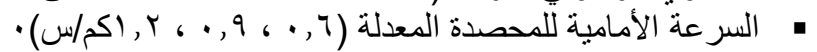

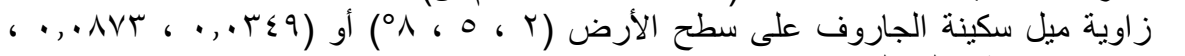

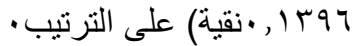

وقد تم التوصل للنتائج التالية:

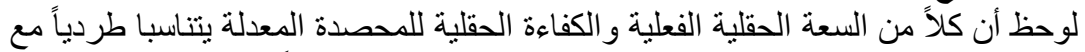

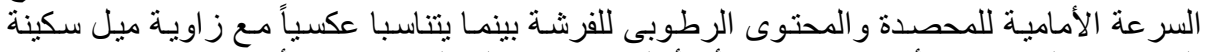

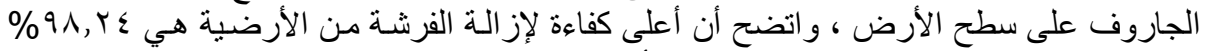

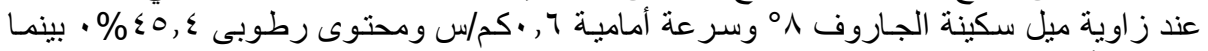

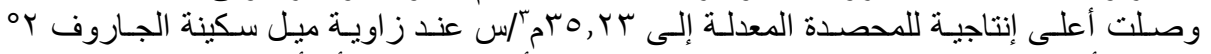

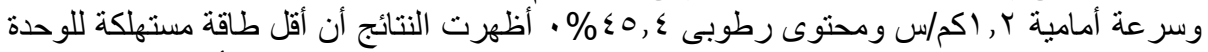

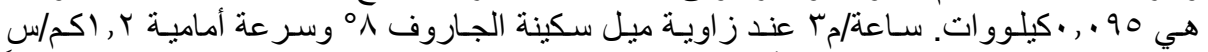

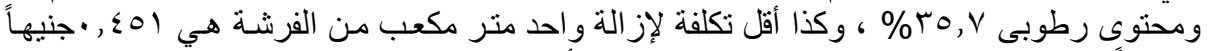

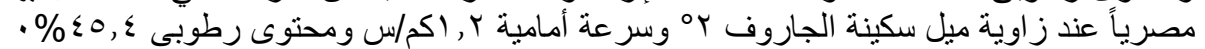

